\title{
ESQUIMÓ, DE FABRÍCIO CORSALETTI
}

Cristiane Rodrigues de SOUZA ${ }^{54}$

CORSALETTI, F. Esquimó. São Paulo: Companhia das letras, 2010. 76 p.

Fabrício Corsaletti publicou seu primeiro livro de poemas, Movediço, em 2001, com prefácio do poeta, crítico e professor de Literatura da USP, Alcides Villaça, volume relançado, ao lado de três outros livros, em Estudos para seu corpo (2007). A vida na cidade do interior de São Paulo, Santo Anastácio, abandonada por Fabrício ao seguir rumo à capital para cursar Letras, é tema de seu primeiro livro, assim como o amor e o erotismo, assuntos que permanecem em Esquimó.

A retomada do passado e da família marca os versos do livro de 2010, em que o poeta elege como pasárgada a casa avistada na paisagem da infância - "aquela casa à beira/ dos trilhos do trem/ na segunda curva/ do caminho do sítio/ do tio" -, lugar em que poderia escapar da rotina diária feita de pesadelos, escrita e trabalho, intercalada com pausas "para o almoço" e para o "amor". Casa que lembra o "casarão de madeira/ pintado de vermelho/ vivo/ que [ele] via/ fascinado", anunciado em poema anterior, mas sobre o qual decide não falar, ou a casa "com janelas/ para [sua] nostalgia", de texto adiante, relações que mostram como os poemas de Esquimó dialogam e se completam.

O tema da família e do passado é quase dado como encerrado, em certa altura do livro, no "penúltimo poema sobre meus pais", pois, como "[seus] pais pediram/ que não escreva mais/ sobre eles", Fabrício anuncia a "procura de temas/ que justifiquem// [suas] lágrimas". Como falar da tristeza da família para justificar a própria é recurso utilizado pelo eu-lírico que está "ficando cada vez mais triste", Fabrício decide "descongelar [seu] amigo esquimó" para beber com ele e ver o que acha sobre a impossibilidade de continuar a "justificar [...] seus remorsos" por meio de poemas que retomem a família.

O esquimó que dá título ao livro é citado, sem maiores explicações, em dois poemas: descongelado e chamado a beber rum com Fabrício, em um deles, e venerando uma mulher não nomeada, em outro - "você se divertia/ sendo adorada por um

54 Centro Universitário Barão de Mauá, CEP 14090-180, Ribeirão Preto, SP, Brasil c_rodrigues17@yahoo.com.br 
esquimó”. O ser do frio, marginal em nossa sociedade, mas capaz de instaurar diálogo com o poeta, tomado de empréstimo de poema de Joca Reiners Terron - "Meu amigo esquimó nunca me deixa só" - e de música de Bob Dylan - "Quinn the Eskimo", como afirma Corsaletti em entrevista ao jornal O estado de S. Paulo (2010), parece funcionar bem como seu alter ego, principalmente se levarmos em conta que, em oposição ao poeta, completando-o, está a imagem quente da amada: "o vento quente/ que [o] acompanha", a "gueixa roxa" que apareceu quando "a paisagem estava/ quase toda/ apagada", aquela cujo nariz "lembraria o focinho/ de uma capivara/ de pelúcia" e que faz o poeta se sentir "exilado/ dentro [dele] mesmo", em suma, a única pessoa do mundo "que não está quebrada".

A procura do calor como solução para a vida urbana fria aparece no poema de Terron, em que a quentura é oferecida ao eu-lírico, paradoxalmente, pelo amigo estrangeiro, capaz de encontrá-la em meio ao gelo. Já na canção de Dylan, Quinn, o esquimó, aparece como alternativa à rotina da vida, já que, ao aparecer, faz "todo mundo pular de alegria", deixando de lado a monotonia e o desespero. De forma semelhante, nos poemas do livro de Corsaletti, há também a busca de completude para o eu "quebrado", anunciado no poema de abertura do livro.

O primeiro poema de Esquimó faz referência, por meio do título - "Everything is broken" -, a outra música de Bob Dylan, retomando da letra da canção a repetição insistente do vocábulo "quebrado(a)" que, com vogal aberta em posição tônica, possui sonoridade oposta à de seu equivalente inglês. Em meio a afirmações entrecortadas por enjambements - "minhas botas/ estão quebradas" -, a repetição da palavra "quebrado", enfatizada pela sonoridade do vocábulo, assume significados múltiplos - cansado, fragmentado, lânguido - que percorrem os poemas de Esquimó, em que o eu-lírico se anuncia como aquele que quer "cortar [sua] cabeça com uma espada/ e chorar pelo resto da vida".

O eu poético que escolhe carregar a dor da culpa como "um/ dedo a mais", não aceitando se arrepender ou se perdoar, afirmando-se no poema final "cansado da vida", ou seja, quebrado, como anunciado no poema de abertura, intercala, no entanto, à melancolia e à tristeza, momentos de leveza, conseguidos, muitas vezes, por meio de humor, como ao revelar a felicidade por viver entre as próprias orelhas que "nunca botaram outro malandro no lugar" ou quando agradece aos rabanetes "que resistiram a nove anos de análise" e à analista que "não questionou [sua] paixão por rabanetes". 
Talvez por se sentir "quebrado", ou seja, partido do mundo, o eu-lírico procure no outro a complementação, figurativizada por meio da imagem de dois opostos que se conjugam, no poema "A história de Chang e Eng", dois gêmeos siameses que "fizeram fortuna/ se apresentando em circos/ ao redor do mundo", poema baseado em fatos reais. Os irmãos formam a totalidade desejada pelo poeta - "Chang bebia e era temperamental/ [e] Eng era plácido e gostava de ler" - já que são a união da divisão sentida no próprio corpo do eu-lírico de Esquimó.

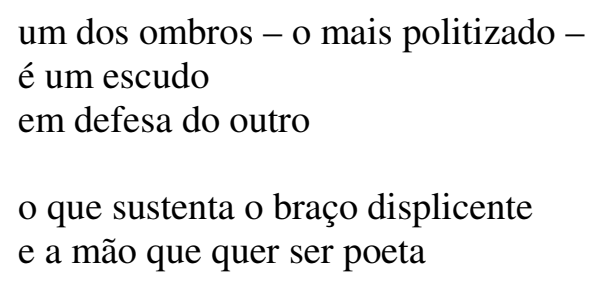

Os gêmeos Chang e Eng sintetizam os dois eus do poeta, formado, por um lado, pelo ser social, chamado a resolver problemas práticos como o encanamento que vaza na cozinha e a se preocupar com o meio ambiente e a política, e, por outro, por faceta marginal semelhante ao esquimó em meio à cidade ou ao pato que o poeta deseja pensar ser, por um momento - "pato gordo/ e libidinoso/ à beira da lagoa/ correndo atrás de uma pata".

Ao final do poema dos irmãos siameses, ao afirmar que "esta não é a [sua] história/ esta é a história de Chang e Eng", o poeta deixa transparecer que, na verdade, a história é sobre ele mesmo. No início de seu livro, a série de poemas intitulados "Variações", ao oporem pares simetricamente opostos, construídos por meio de pequenas alterações que causam mudanças de sentido, nos ensina, ao retomar a técnica de construção musical, que dentro de cada afirmação está, de forma latente, o seu oposto - "sou dos que vivem/ como se nada tivesse acontecido"; "não sou dos que vivem/ como se nada tivesse acontecido". Da mesma forma, a afirmação ao final do poema dos siameses contém o seu contrário: esta é a história [do poeta]/ esta não é a história de Chang e Eng.

A variação percorre o livro de Corsaletti, aparecendo em meio a vários textos, formando, muitas vezes, pares de versos simetricamente opostos. Além disso, os dois momentos em que o recurso da variação é colocado em destaque - no grupo de poemas disposto após o texto de abertura e no poema de fechamento do livro - construindo o início e o final de Esquimó, forma, por meio de sua disposição, também uma simetria, 
pois enquanto "Variações" mudam sentidos por meio de pequenas alterações, o poema de fechamento, "Seu nome", é construído por versos que, mantendo, quase todos, o final inalterado - "seu nome" -, são drasticamente modificados por meio de associações semânticas.

Assim, a estrutura do livro de Fabrício reproduz uma das preocupações fundamentais do eu poético de Esquimó, a saber, a tentativa de compreender e legitimar o mundo "quebrado" e o ser cindido do poeta. Afinal, "tem gente que tem uma máscara/ tem gente que tem duas".

\section{REFERÊNCIAS}

CORSALETTI, F. Esquimó. São Paulo: Companhia das letras, 2010.

CORSALETTI, F. Entrevista - Um esquimó na Paulicéia. Disponível em: <http://pphp.uol.com.br/tropico/html/textos/3214,1.shl >. Acesso em 5 jun. 2011.

CORSALETTI, F. Entrevista - Fabrício Corsaletti lança Esquimó. Disponível em: $<$ http://tv.estadao.com.br/videos,fabricio-corsaletti-lanca-esquimo,92369,253,0.htm>. Acesso em 9 jun. 2011. 